\title{
US Senate gets tough on animal activists
}

[WASHINGTON] Following attacks by animalrights activists on research facilities in Minneapolis and San Francisco, the US Senate has moved to toughen federal penalties for such crimes - including the possibility of the death penalty if anyone is killed in an attack.

The new measure also requires the Federal Bureau of Investigation (FBI) to establish a 'National Animal Terrorism and Ecoterrorism Incident Clearinghouse'. This would centralize information on attacks gathered by federal, state and local law enforcement agencies, which have had difficulty making arrests and convictions in cases of lab vandalism.

An amendment aimed at those convicted of attacking animal facilities - whether zoos, fur farms or research labs - and causing more than $\$ 10,000$ worth of damage was included in a broad juvenile crime bill that was passed by the Senate late last month.

Under the amendment, offenders would face up to five years in prison and fines of up to double the cost of the damage caused. If explosives or arson were used, prison terms would be at least five years and up to 20 .

The amendment was written by Senators Orrin Hatch (Republican, Utah) and Dianne Feinstein (Democrat, California), and passed by a vote of 85 to 13 . It toughens the criminal penalties in the Animal Enterprise Protection Act of 1992, which dictated a maximum prison term of one year for attacks causing property damage, and left unspecified the prison term for attacks in which anyone is killed.

"[The amendment] is a useful move," says Walter Low, a professor of neurosurgery at the University of Minnesota whose lab was ransacked by activists in April (see Nature 398, 553; 1999). The Animal Liberation Front claimed responsibility. "Hopefully it will cause these people to think more carefully about their actions. This kind of violence and vandalism has no place in a civilized society."

Research lobbyists also praised the measure. "It gives the Animal Enterprise Act more teeth," says Mishka McCowan, programme director at Americans for Medical Progress, a group based in Virginia that was set up to counter the animal-rights movement.

McCowan says the vandalism at the University of Minnesota - and a smaller-scale attack less than three weeks later at the University of California at San Francisco (see right) — were prompting "concern that this would become a trend. The stiffening of the penalties alleviates that a little bit."

But animal-rights activists say the amendment will not make any difference. "Nobody in any social movement has ever been deterred from breaking and entering or arson because the penalties have been elevated," says Ingrid Newkirk, president of People for

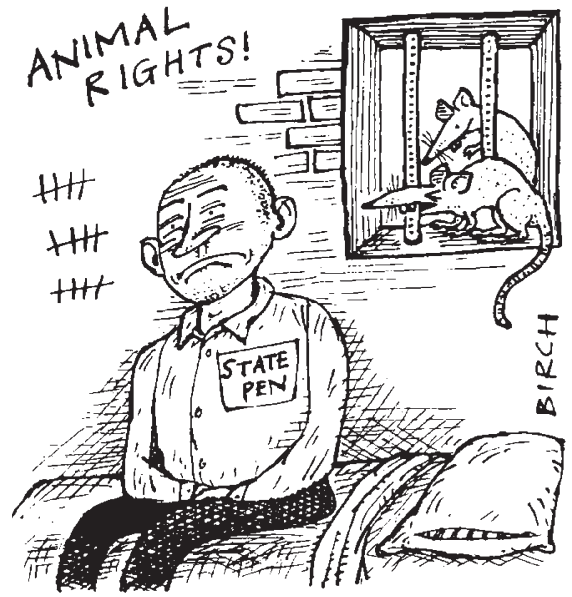

the Ethical Treatment of Animals (PETA), based in Norfolk, Virginia. She calls the amendment "a knee-jerk piece of legislation".

Newkirk says PETA uses only peaceful civil disobedience, but adds that researchers have brought the more violent incidents on themselves. "The laboratories, because they fight even the most modest proposals to improve the living and dying conditions for animals in their enterprises, are responsible for an escalation of [violence] by people frustrated that they can't achieve change through normal channels."

Civil libertarians challenged what they called the amendment's unconstitutional focus on animal-rights activists - especially when invoking the death penalty. "We think that criminal laws should be equitably enforced across the entire population," says Rachel King, legislative counsel at the American Civil Liberties Union. "No one group should be singled out for harsher punishment than any other."

King claims that the death penalty provision was introduced surreptitiously into the bill. Most senators, who were voting on nearly 200 amendments to the bill, had no idea that the animals amendment contained a new capital crime, she says.

The amendment, which contains many other provisions dealing with youth gangs, originated with Hatch, a member of the advisory council of Americans for Medical Progress. In his home state, a youth gang that eschews the eating and wearing of animal products has attacked animal facilities.

Barbara Rich, executive vice-president of the National Foundation for Biomedical Research, says the FBI clearinghouse is particularly welcome. "We've had very few successful prosecutions" after attacks on research labs, she says. "Anything that will encourage local and federal law enforcement to pursue these things vigorously we think is a good idea."

The House of Representatives is expected to take up a juvenile crime bill later this month. If this does not include a similar provision, the measure could still be retained in a final version negotiated in a House-Senate conference.

Meredith Wadman

\section{San Francisco scientists hit by growing protests}

[WASHINGTON] When a dozen laboratories at the University of Minnesota's Twin Cities campus were attacked in early April, word of some $\$ 2$ million worth of damage and 116 lost animals spread quickly in the scientific community.

Less attention was given to an attack on three labs at the University of California, San Francisco (UCSF), on 23 April. In conjunction with a peaceful protest by about 60 demonstrators, several labs were broken into by a smaller group.

This group threw computers and centrifuges on the floor in the Cell Culture Facility, and damaged surgical equipment in a cardiology lab. Activists then entered a neurology lab and released four transgenic mice - two with scrapie being used to develop diagnostic methods for 'mad cow disease'. Three activists were charged with criminal trespass. The damage is estimated to cost $\$ 11,000$.

The incident is part of an unsettling pattern, says Ara Tahmassian, UCSF's assistant vice-chancellor for research services. Peaceful demonstrations have been occurring regularly on the campus for a year, he says. But three times in the month before the campus break-in, activists demonstrated at the home of Steven Cheung, an otolaryngolist who studies hearing loss using squirrel monkeys as a model. What Cheung believed to be a burning effigy of himself was thrown at the house.
"There is a kind of radicalism that we haven't seen before. I think we [in the research community] need to be a lot more careful not to take this lightly," says Tahmassian. "My message to the campus has been: be on guard, times have changed."

In Minnesota, police have made no arrests. But Kevin Kjonaas, the Animal Liberation Front spokesman who said the group claimed responsibility for the attack, has been subpoenaed to appear before a federal grand jury this month. Police will not say whether he is a suspect in the attack.

The Minnesota legislature passed a bill last month imposing civil damages of at least $\$ 5,000$ for the unauthorized release of laboratory animals.

M. w. 